УДК 821.161 .2

Гурдуз А. I., кандидат філологічних наук, доцент кафедри української мови і літератури Миколаївського національного університету імені В. О. Сухомлинського

\title{
МІФОПОЕТИЧНЕ МОДЕЛЮВАННЯ В ПРОЗІ ОЛЕНИ ПЕЧОРНОЇ Й АЛЛИ РОГАШКО
}

У пропонованій статті вперше визначено типологічну подібність $і$ своєрідність міфопоетичного моделювання в прозі Олени Печорної й Алли Рогашко. Ключовими при изьому $\epsilon$ питання виявлення основних засобів створення міфопоетичної атмосфери в творах названих авторок, а також трактування місия цих письменниць у системі сучасної їм національної жіночої прози.

Ключові слова: мотив, модель, кониепт, міфопоетика, тілоцентризм, навіювання, психологізм, типологія.

В предлагаемой статье впервые определены типологическое сходство и своеобразие мифопоэтического моделирования в прозе Елены Печёрной и Алль Рогашко. Ключевыми при этом являются вопросы выявления основных средств создания мифопоэтической атмосферы в произведениях названных авторов, а также трактовки места этих 
писательнии в системе современной им национальной женской прозы.

Ключевые слова: мотив, модель, конщепт, мифопоэтика, телоцентризм, сугzестия, психологизм, типология.

In this article the typological similarity and originality of the mythopoetical modeling in the prose by Olena Pechorna and Alla Rogashko are certain for the first time. The key in this context become such questions: the determination of the main facilities of creation of the mythopoetical atmosphere in the artistic works of the named authors and also the finding of the interpretation of these writers' place in the modern to them system of the national woman prose.

Keywords: motive, model, concept, mythopoetics, bodycentrizm, suggestion, psychologism, typology.

У високій динаміці й різноманітності літературного процесу в Україні перших десятиліть XXI ст. актуалізовані, як ніколи, питання міфотворчості, гендерного плану, жанрової трансформації, які комплексно чи не найінтенсивніше і вельми продуктивно виявляються в корпусі жіночої прози. Її дослідження різної масштабності й спрямованості (С. Філоненко, Ю. Кушнерюк, Г.-П. Рижкової, Н. Герасименко та ін.) тривають переважно в координатах масової літератури й часом потребують методологічного уточнення й узгодження, систематизації, посилення об'єктивності оцінки, в першу чергу, через компаративний акцент. Особливий інтерес тут викликає творчість митців, орієнтованих на жанрово синтетичну прозу, якій властива мозаїчна чи комбінаторна природа міфопоетичної парадигми.

Міфопоетична організація помітних у національній жіночій романістиці творів Олени Печорної й Алли Рогашко в своїй основі відповідає мозаїчному типу (за винятком «Фортеці для серця» О. Печорної, де бачимо відповідний лінійний елемент [Герасименко 2015:60]) і відрізняється від аналогічних систем більшості любовних містично-фентезійних романів України кінця XX - перших десятиліть XXI ст., сформованих на базі комбінованої (лінійно-мозаїчної) моделі і ставка в яких переважно зроблена на «формульний» і популярний, частіше багато в чому запозичений iз західноєвропейських i північноамериканських зразків сюжет (серед творів названої групи можна назвати «Мантру-оману» Вікторії Гранецької, численні романи Дари Корній та ін. [Гурдуз 2014:62]). Чи не найбільш оригінальні й самобутні художні тексти О. Печорної й А. Рогашко за набором і характером засобів досягнення міфопоетичного ефекту; цей же критерій свідчить про типологічну подібність 
творів названих мисткинь i заслуговує на окреме вивчення. Така співвідносність міфопоетичних технік О. Печорної й А. Рогашко нами висвітлюється вперше, як і власне зіставлення їх художніх текстів. Якщо проза О. Печорної розглядається переважно аспектно (концепт пам’яті в «Грішниці» аналізує В. Владимирова, контекстно цей роман 2010 р. проходить у статтях Г. Швець і О. Архіпової; «Кола на воді» 2013 р. задовольняються рецензіями (на зразок роздумів О. Герасименко), а «Фортеця для сердця» 2013 р., крім того, коментована в аналітичному огляді жіночої прози Н. Герасименко [Герасименко 2015:60]), і єдине системне дослідження романістики авторки містять розвідки А. Гурдуза, де на тлі панорами жіночої романістики України початку XXI ст. простежується художня природа визначальної для творів письменниці мотивіки в контексті міфопоетики і крізь призму традиції й новаторства [див.: Гурдуз 2014; Гурдуз 2015], то твори А. Рогашко ще не ставали об'єктом комплексного літературознавчого аналізу (поряд 3 традиційною для Галини Пагутяк емоційною рекомендацією «Осіннього Рондо місячної ночі» 2010-2011 pp. [Рогашко 2015:5-6], назвемо студію А. Гурдуза про природу міфопоетики цього роману [Гурдуз 2016]). Метою пропонованої статті $\epsilon$, отже, вперше здійснюване визначення типологічної подібності i своєрідності міфопоетичного моделювання в прозі О. Печорної й А. Рогашко. Ключовими при цьому стають питання а) виявлення основних засобів створення міфопоетичної атмосфери в творах названих авторок; б) трактування місця цих письменниць у системі сучасної їм національної жіночої прози.

Романи О. Печорної й А. Рогашко достатньо самобутні на міфопоетичному рівні організації порівняно 3 масивом жіночої романістики кінця XX- перших десятиліть XXI ст., i на особливу увагу заслуговує провідний структурно-формальний принцип формування в них міфопоетичної атмосфери. Три видані на сьогодні романи О. Печорної виявляють між собою специфічний внутрішній зв’язок, причому найтісніший - «Грішниця» і «Кола на воді», а визначуваний через аналіз звертання авторки до художньої спадщини М. Коцюбинського - «Фортеця для серця» стосовно названих творів. 
Так само внутрішній системний зв'язок спостерігається у прозі А. Рогашко (з долученням й оповідань авторки), кращий роман якої нині - «Осіннє Рондо місячної ночі».

Відчутне в романах О. Печорної ірраціональне аранжування присутнє не стільки на сюжетно-образному рівні, скільки в плані певного почуттєвого навіювання читачу. Такому ефекту сприяють характерні для манери письменниці виражена тілесність (навіть тілоцентризм) i тенденція до всезагального системного уособлення природних явищ, об’єктів, абстракцій i т. ін. У результаті система персонажів у іiі книгах специфічно розширюється: так, у «Колах на воді» статус персонажа (квазіперсонаж) по праву належить i спеці, і ночі, й озеру; титульним же образом стає вода, поетика якої ніби підкорює собі текст [Гурдуз 2015:73]. Таке «оживлення» в прозі авторки природних явищ, об’єктів тощо - «визначальну ознаку» стилю О. Печорної [Герасименко 2015:60] - можна співвіднести 3 рисою психологічного імпресіонізму М. Коцюбинського (пригадаймо ті ж Ниви у червні, Сонце, Людське горе, Утому, Залізну руку города в його «Intermezzo»), до спадщини якого мисткиня звертається системно. Побічний ефект названого почуттєвого навіювання - посилена сентиментальність іiі тексту.

Формуванню міфопоетичної парадигми романів О. Печорної сприяє, крім іншого, властиве іï манері бінарноопозиційне вибудовування художньої канви творів. Саме в такий спосіб увиразнений образ пекла на землі у «Грішниці», який переходить і в наступні «Кола на воді». У дебютній книзі авторки героїня постає як ангел, залишений у не належному для нього місці - пеклі [Печорна 2013:20] і змушений іти дорогою страждань. У «Колах на воді» ж амбівалентність стихії води корелює з відповідною суперечливістю семантики образу сонця i його метафоричного продовження - концепту спеки та зумовлена положенням, що люди винні в перетворенні раю природи на пекло: «Рай знищили вже за годину» [Печорна 2013 Кола:13].

Еволюція стилю О. Печорної засвідчує синтез в іï прозі української літературної традиції і власних новаторських спроб. Перефразовуючи 
А. Меншій, можна сказати, що формування наративної стратегії Олени Печорної пов'язане 3 наративною логікою прозописьма М. Коцюбинського [Меншій 2016:533], письменниця перебуває в силовому полі мистецької «школи» автора «Тіней забутих предків», що, як і в разі 3 хронологічно ранішими іiі представниками (передовсім, Є. Гуцалом, В. Дроздом, Р. Іваничуком, Вал. Шевчуком), впливає на стиль, збагачує мистецьку палітру письменниці [Меншій 2016:535].

Параболізм сприйняття дебютного роману А. Рогашко «Осінне Рондо місячної ночі» і його різнорівневих складників мотивований уже іншими, ніж у творах О. Печорної, причинами - переважно «вимогами» винесеної в назву музичної форми (рондо) i реалізується шляхом особливого порядку розміщення, повторюваності й видозміни в тексті окремих словосполучень і речень, які набувають потрібний автору символізм і підтекст саме в заданій комбінації. «Опорні» лексеми при цьому стають оказіональними міфологемами тексту, упродовж сюжету функціонуючи як містичні вказівники. Такі первісні ключові міфологеми в романі відповідають чотирьом лексемам-складникам його назви, які виступають маркерами романтичного антуражу подій роману: це осінь, рондо, місячна пора і ніч [Гурдуз 2016:97]. Подібний ефект виникає за рахунок усезагального оживлення в прозі О. Печорної, коли виокремлювані в такий спосіб образи набувають квазіперсонажні функції. У творі А. Рогашко історія кохання однієї трагічно загиблої пари (Софії і Степана) віддзеркалюється в житті іншої (Любки і Любомира) як у своїй реінкарнованій версії [Рогашко 2015:186]. Поєднання доль двох пов'язаних у часі закоханих пар - зі світів старого і нового Львова - в А. Рогашко художньо обіграно, зокрема, у вигляді химерних пригадувань, дежавю, передчуттів героїв [Рогашко 2015:84; Рогашко 2015:191]. При цьому часові й просторові атрибути обох історій перегукуються, забезпечуючи впізнаваність і відповідне системне нагадування в тексті, а також містять власну внутрішню логічну схему. Подібне бачимо в малій прозі письменниці.

Указані численні акцентовані образи й мікрообрази, пов’язані 3 ними 
сцени - явлення таємничої жінки в чорному, яка загубилася в часі, романтична окриленість героїні (Софії і Любки; закохана жінка в оповіданні «Їхній світ удвох» відчуває, як «...за спиною виросли крила - наче крила того Фенікса, щуо, відродивиись, мав знову злетіти у своє піднебесся» [Рогашко 2016:140]), «бліді квіти» на деревах і тривожна поведінка ворон, схожа на осінь весна тощо - в своїй повторюваності утворюють мережу символічних перегуків, що сприймаються як система містичних знаків, яка орієнтує на тривожний розвиток дії, навіює думку про циклічність і відносність часу, універсалізації зображуваних подій i дозволяє кваліфікувати роман як різновид міського фентезі з ретро-похилом. Пов’язані з жінкою в чорному повторювані фрагменти тексту варіативні, що відповідає принципу рондо, вони становлять своєрідний рефрен роману, певно відображаючи й динаміку сюжету. Доречно пригадати подібну практику в романі В. Гранецької «Мантра-омана» 2011 р., де повторювані фрагменти функціонально співвідносні 3 рефренами в творах пісенного жанру. Завдяки цьому процес читання «Мантри-омани» певно нагадує проказування розчиненого в ऑii тексті набору мантр, які врешті зливаються в одну умовну «мантру» роману. Виявлені закономірності творів А. Рогашко і В. Гранецької типологічно подібні й викликані специфікою обраних «жанрових» форм (відповідно рондо і мантри). При цьому комбінаторна міфопоетика твору В. Гранецької доповнена вказаними повторами, тимчасом як для міфопоетики роману А. Рогашко коментовані повтори структуротвірні. Відчутна певна подібність «Осіннього Рондо...» і до «Зла» Людмили Баграт 2002 р., де окремі текстові повтори також становлять кільцевість композиції і система містичних знаків робить очікуваною трагічну розв'язку.

До речі, як і в «Колах на воді» О. Печорної, важливим в «Осінньому Рондо...»є асоціативний комплекс води [Гурдуз 2016:98].

Співвідносна романам А. Рогашко міфопоетична організація iї малої прози. Наприклад, в оповіданні «Їхній світ удвох» любовна лінія також проникнена «легким илейфом містичності» [Рогашко 2016:131], розгортається 
в системі повторюваних часопросторових знаків з довільно обраним авторкою структурно-смисловим центром (кулон у вигляді Фенікса: «Усе обертається довкола... Фенікса» [Рогашко 2016:155]), чим забезпечується циклізація часу й створення, знову ж таки, казкової атмосфери (міста Львова). Правда, фіксуємо дещо більшу близькість цього тексту (де актуалізована міфологема Фенікса і де героїня спочатку зустрічає обранця в ірраціональному вимірі - своїх мрій) до корпусу національної любовної містичної прози [Гурдуз 2014].

Як видно, твори молодих письменниць О. Печорної й А. Рогашко відзначені (більш чи менш вдалими) спробами сказати нове слово в українській літературі при дотриманні (О. Печорною) і врахуванні (А. Рогашко) національної традиції; їх міфопоетичний потенціал розкрито відносно автономно стосовно класичного міфологічного чи авторського міфопоетичного корпусу, і в цьому підхід А. Рогашко подібний до манери О. Печорної (особливо в «Колах на воді»; в наступному романі А. Рогашко «Крізь безодню до світла» риторика дещо змінюється). Також зближують авторок їх увага до техніки написання, власне до слова, побудови тексту, що, на жаль, далеко не завжди характерно для сучасної української прози. Міфопоетична парадигма домінантного мозаїчного типу творів аналізованих письменниць безумовно продуктивна, здатна конкурувати з відповідною комбінованою міфопоетичною матрицею, що остання як органічний стандартам масового мистецтва варіант «джойсівської» моделі міфотворчості нині стала чи не цілком панівною в Україні. Переобтяження літературно-мистецького процесу такими зразками сприймається критикою прихильно i деформує уявлення про просування пошуків національної міфотворчості вперед, оскільки інтенсивність процесу гарантується швидше «кафкіанською» моделлю міфотворчості, а така в українській літературі (i, наприклад, у білоруській) початку XXI ст. надто незначна [Гурдуз 2016:100]. У результаті національна літературно-мистецька система на шляху міфопоетичних пошуків переживає кризу не тільки через складність руху в бік «кафкіанської» моделі, але й через штучну ставку на домінантну в світі «джойсівську» модель, яка, в свою чергу, значно вичерпана i 
демонструє ознаки кризи.

Подальше вивчення динаміки основних художніх характеристик (у першу чергу, міфопоетики) прози О. Печорної й А. Рогашко в системі української й світової жіночої романістики уявляється перспективним i потрібним, як i уточнення національних критеріїв якості художньої продукції в умовах міфотворчих пошуків XXI ст.

\section{БІБЛІОГРАФІЯ}

Герасименко 2015 - Герасименко Н. Жіноча література: чи справді «рожева»? / Ніна Герасименко // Слово і Час. - 2015. - № 3. - С. 56-69.

Гурдуз 2014 Мотив - Гурдуз А. I. Мотив сходження в романі Олени Печорної «Грішниця» / А. І. Гурдуз, К. Б. Барковська // Наукові праці Кам'янець-Подільського національного університету імені Івана Огієнка : Філологічні науки. - Кам’янець-Подільський : Аксіома, 2014. - Вип. 36. C. $50-53$.

Гурдуз 2015 - Гурдуз А. І. Концепт води в романі Олени Печорної «Кола на воді» / А. І. Гурдуз // Наукові праці Кам'янець-Подільського національного університету імені Івана Огієнка : Філологічні науки. - Кам'янецьПодільський : Аксіома, 2015. - Вип. 39. - С. 72-75.

Гурдуз 2014 - Гурдуз А. I. Міфопоетика «жіночого» містичного любовного роману першого десятиліття XXI століття в Україні / А. I. Гурдуз // Науковий вісник Миколаївського державного університету імені В. О. Сухомлинського : зб. наук. пр. Сер. : Філологічні науки (літературознавство) / гол. ред. В. Д. Будак, гол. ред. сер. О. С. Філатова. Миколаїв : МНУ ім. В. О. Сухомлинського, 2014. - Вип. 4.13 (104). - С. 61-68.

Гурдуз 2016 - Гурдуз А. Структурна домінанта міфопоетики роману Алли Рогашко «Осінне Рондо місячної ночі» // Науковий вісник Миколаївського національного університету імені В. О. Сухомлинського. Сер. : Філологічні науки : (літературознавство) : зб. наук. пр. / за ред. О. С. Філатової. Миколаїв : МНУ ім. В. О. Сухомлинського, 2016. - Листопад. - Вип. 2 (18). C. $96-101$.

Меншій 2016 - Меншій А. «Напоєні красою слів твоїх...»: «школа» 
М. Коцюбинського в українському постімпресіонізмі : моногр. / Аліса Меншій. - Миколаїв : Іліон, 2016. - 580 с.

Печорна 2013 - Печорна О. Грішниця / Олена Печорна ; передм. М. Іванцової. - 2-е вид., стереотип. - Харків : Клуб сімейного дозвілля, 2013. $288 \mathrm{c}$.

Печорна 2013 Кола - Печорна О. Кола на воді / Олена Печорна ; передм. Г. Пагутяк. - Харків : Книжковий клуб «Клуб сімейного дозвілля», 2013. $288 \mathrm{c}$.

Рогашко 2016 - Рогашко А. Їхній світ удвох / Алла Рогашко // Львів. Смаколики. Різдво : зб. / укл. і передм. Н. Нікалео. - Харків : Книжковий клуб «Клуб сімейного дозвілля», 2016. - С. 130-165.

Рогашко 2015 - Рогашко А. Осіннє Рондо місячної ночі : роман / Алла Рогашко ; передм. Г. Пагутяк. - Харків : Книжковий клуб «Клуб сімейного дозвілля», 2015. - 208 с. 